\title{
Use of a multiplex-polymerase chain reaction for detection of Salmonella and Chlamydophila psittaci from caged birds
}

\author{
Barış SAREYYÜPOĞLU, Zafer CANTEKINN
}

Department of Microbiology, Faculty of Veterinary Medicine, University of Ankara, 06110, Diskapi, Ankara, Turkey.

\begin{abstract}
Summary: In this study, development of a multiplex-PCR (m-PCR) assay for identification of Salmonellosis and Psittacosis in caged birds was aimed. DNAs extracted from Salmonella spp. strains from the collection of our department and Salmonella spp. isolates from caged birds in addition to the extracted DNA samples belong to two different Chlamydophila psittaci clinical strains (strain 6BC and a strain isolated from a parakeet), constituted the material of the study. A m-PCR assay was developed which use iroBF and iroBR primers to specifically amplify $606 \mathrm{bp}$ sequence of iroB gene of Salmonella spp. DNA in the same reaction mix and with the same conditions, CpsiA and CpsiB primers were used to amplify $300 \mathrm{bp}$ sequence of pmp gene of $C$. psittaci. The specificity and the sensitivity of the assay were determined by using positive controls (Salmonella and Chlamydia DNA samples). We believe that the newly developed m-PCR assay is a fast, reliable and an economic assay, which has the potential for direct identification of Salmonella spp. and C. psittaci from the clinical samples.
\end{abstract}

Key words: Caged birds, Chlamydophila psittaci, identification, multiplex-PCR, Salmonella spp.

\section{Kafes kuşlarında Salmonella ve Chlamydophila psittaci'nin saptanmasında multiplex-polimeraz zincir reaksiyonu tekniğinin kullanılması}

Özet: Bu çalışmada, Salmonellosis ve Psittacosis'in tanısında kullanılmak üzere bir multipleks-polimeraz zincir reaksiyonu (m-PZR) tekniği geliştirilmesi amaçlandı. Ankara Üniversitesi Veteriner Fakültesi Mikrobiyoloji Anabilim Dalı suş koleksiyonunda yer alan Salmonella suşları, kafes kuşu orijinli Salmonella izolatları ve bunlardan izole edilen DNA örnekleri dışında yurt dışından sağlanan ve iki farklı Chlamydophila psittaci klinik suşundan izole edilmiş DNA örnekleri çalışma materyalini oluşturdu. Çalışmada, Salmonella türlerinde iroB genini kodlayan sekansın 606 bp'lik porsiyonunu spesifik olarak amplifiye eden iroBF ve iroBR primer çifti ile Chlamydophila psittaci'nin pmp genlerinin 300 bp'lik sekansını amplifiye eden CpsiA ve CpsiB primer çiftinin aynı reaksiyon karışımı ve şartlarında çalışacağı bir m-PZR tekniği geliştirildi. Pozitif kontrol Chlamydophila psittaci DNA'larının dışında, kendi laboratuvar izolatları ve suşlarından izole edilen DNA örnekleri kullanılarak tekniğin spesifite ve sensitivitesi de belirlendi. Sonuç olarak, klinik materyallerden direkt tanı potansiyeli de bulunan tekniğin kafes kuşlarında Salmonella spp. ve $C$. psittaci'nin tanısında hızlı, güvenilir ve ekonomik bir teknik olduğu düşünülmektedir.

Anahtar sözcükler: Chlamydophila psittaci, kafes kuşları, multiplex-PCR, Salmonella spp., tanı.

\section{Introduction}

Salmonellosis and Psittacosis are two of the most important infections of caged birds caused by Salmonella spp. and Chlamydophila psittaci (C. psittaci), respectively. Both of the agents are significant, in that, they cause zoonoses $(8,20)$.

Laboratory diagnosis of Salmonella and C. psittaci requires time and labor intensive procedures. Diagnosis is by culture of feces, blood, spleen, liver and intestinal contents $(20,23)$. Since the culture of clinical material and final identification of the causing agent lasts for at least a week, alternative identification methods such as molecular detection methods like polymerase chain reaction (PCR) have been developed $(4,7,10,13,22)$.

A number of reports on the use of PCR assays to detect C. psittaci have appeared in the literature $(6,11$,
$12,16,17)$. These sensitive assays were able to rapidly detect $C$. psittaci DNA in samples of tissues, feces and choanal cleft and cloacal swabs and performed better than traditional tissue staining methods and culture especially with mishandled and improperly sampled specimens $(18,19)$.

Multiplex-PCR (m-PCR) is a type of PCR in which two or more target sequences are simultaneously amplified in the same reaction (9). Since more than one target sequence can be amplified with this assay, it has the potential to produce considerable savings of time and effort within the laboratory without compromising test utility (5).

We aimed to develop and use a m-PCR assay which simultaneously detects two important pathogens which cause significant infections in caged birds. 


\section{Materials and Methods}

DNA of laboratory strains and clinical isolates: Laboratory strains of Salmonella enterica subsp. enterica serovar Pullorum (AUM21), S. Gallinarum (AUM27), $S$. Enteritidis (AUM32), $S$. Typhimurium (AUM41) from the archive of Department of Microbiology, Faculty of Veterinary Medicine, Ankara University, as well as, Salmonella spp. isolates from clinical isolates originated from caged birds were used as positive control Salmonella DNA. C. psittaci (strain 6BC and a strain isolated from a parakeet) and Chlamydia trachomatis DNAs were kindly provided by Prof. Bernhard Kaltenboeck (Department of Pathobiology, College of Veterinary Medicine, Auburn University), were used as positive and negative controls, respectively.

DNA extraction from Salmonella serovars: For extraction of Salmonella DNA from plate cultures incubated overnight, one or two colonies were suspended in $200 \mu \mathrm{l}$ of DEPC treated water (Fermentas, Vilnius, Lithuania). The suspension is added to spin columns of QiaAmp DNA mini kits (Qiagen, Hilden, Germany) and extraction protocol was followed according to the instructions reported in the kit manual.

DNA extraction from necropsy materials obtained from a caged bird: DNAs were extracted from the swab samples (ocular and cloacal), internal organs (liver, spleen, lungs), intestines with Qiagen DNA tissue kit and feces with Qiagen DNA stool kits (Qiagen, Hilden, Germany) according to the kit instructions.

PCR detection of iroB and pmp genes: Oligonucleotides were iroBF, 5'-TGCGTATTCTGTTT GTCGGTCC-3' and iroBR, 5'-TACGTTCCCACCATT CTTCCC-3' which specifically amplify 606 bp portion of iroB (iron regulated locus B, glucosyl-transferase-like protein) gene in Salmonella spp. (3), and CpsiA, 5'-ATG AAACATCCAGTCTACTGG-3' and CpsiB 5,'-TTGTG TAGTAATATTATCAAA-3' those specifically amplify approximately $300 \mathrm{bp}$ sequence of pmp (polymorphic membrane protein) genes of $C$. psittaci (14). These primer pairs were analyzed in BLAST (http://www.ncbi.nlm.nih. gov/BLAST) searches for determination of probable interactions. PCR assays described in the study of Baumler et al. (3) and Laroucau et al. (14) were used for the detection of iroB and pmp genes.

$M-P C R$ : A m-PCR was developed following a series of standardization studies aiming to find the optimal primer, $\mathrm{dNTP}, \mathrm{MgCl}_{2}$ concentrations, as well as the optimization trials for the establishment of the appropriate amplification conditions such as the determination of the ideal annealing and elongation temperatures and durations. The need for the addition of PCR enhancers were also considered and two of the mostly used PCR enhancers (bovine serum albumin, BSA and dimethyl sulphoxide, DMSO solutions) were comparatively evaluated in the PCR assays. Following the optimization studies m-PCR mix and amplification conditions was determined. M-PCR mix contained 200 $\mu \mathrm{M}$ of each dNTP (Fermentas, Vilnius, Lithuania), $3 \mathrm{mM}$ $\mathrm{MgCl}_{2}, 5 \mu \mathrm{l}$ 10xPCR buffer, $10 \mu \mathrm{M}$ primers, $0.2 \%$ DMSO, $2.5 \mathrm{U}$ Taq polymerase (Fermentas, Vilnius, Lithuania). Two $\mu 1$ of template DNA was included into final volume of $50 \mu \mathrm{lm}$-PCR reaction mix. Amplification consisted of $94^{\circ} \mathrm{C} 2 \mathrm{~min}$, pre-denaturation and 30 cycles of PCR steps of $94^{\circ} \mathrm{C} 30 \mathrm{sec}$, denaturation; $50^{\circ} \mathrm{C} 30 \mathrm{sec}$, annealing; $65^{\circ} \mathrm{C} 2$ min extension, and a final extension of $72^{\circ} \mathrm{C} 10$ $\min$.

Determination of the specificity of the assay: For the determination of the specificity, the m-PCR assay was tested against the DNAs obtained from bacteria such as Staphylococcus aureus, Klebsiella pneumoniae, Escherichia coli, Pseudomonas aeruginosa, Proteus spp., Pasteurella multocida, Chlamydia trachomatis (Table 1).

Determination of the sensitivity of the assay: For the determination of the sensitivity, concentration of the DNA samples ( $C$. psittaci DNAs and DNAs from the selected Salmonella from our laboratory) was calculated with a UV spectrometer. DNAs were 10-fold diluted serially beginning from $20 \mathrm{ng}$ to $2 \mathrm{pg}$ dilutions and equal volumes from these dilutions were used as template DNAs in the multiplex reactions.

\section{Results}

PCR detection of iroB and pmp genes: Six hundred and six base pair portion of the iro $B$ gene was specifically detected in all of the extracted Salmonella DNAs (Figure 1). Specific bands were observed of a size of approximately $300 \mathrm{bp}$ in Chlamydophila DNAs, but not in C. trachomatis (Figure 2).

$M-P C R$ : Both of the amplicons with specific bands sizes of 606 and 300 bps were detected with different Salmonella serovars and C. psittaci strains, respectively (Figure 3). Salmonella and C. psittaci specific bands were detected with m-PCR tests performed with DNA extracted from the necropsy material and feces of a canary.

Specificity of the assay: Neither amplification nor non-specific bands was observed with assay performed with bacteria such as Staphylococcus aureus, Bacillus sp., Klebsiella pneumoniae, Escherichia coli, Pseudomonas aeruginosa, Proteus sp., Pasteurella multocida (Table 1).

Sensitivity of the assay: M-PCR assay was able to detect as low as $20 \mathrm{pg}$ of both DNA (Figure 4). 
Table 1. Bacterial strains tested in PCR assays.

Tablo 1. PCR testlerinde kullanılan bakteri suşları.

\begin{tabular}{|c|c|c|c|}
\hline Strain & $\begin{array}{l}\text { iroB } \\
\text { PCR }\end{array}$ & $\begin{array}{l}p m p \\
\text { PCR }\end{array}$ & $\begin{array}{c}\mathrm{m}- \\
\text { PCR }\end{array}$ \\
\hline Staphylococcus aureus & & & \\
\hline Bacillus sp. & - & - & \\
\hline Klebsiella pneumoniae & - & - & - \\
\hline Escherichia coli & - & - & - \\
\hline Pseudomonas aeruginosa & - & - & - \\
\hline Proteus sp. & - & - & - \\
\hline Pasteurella multocida & - & - & - \\
\hline Salmonella Enteritidis & + & - & - \\
\hline Salmonella Typhimurium & + & - & $\begin{array}{c}+ \\
+\end{array}$ \\
\hline Salmonella Gallinarum & + & - & + \\
\hline Salmonella Pullorum & + & - & + \\
\hline Salmonella spp. isolate from a caged bird & + & - & + \\
\hline Chlamydophila psittaci strain 6BC & + & $\overline{-}$ & + \\
\hline C. psittaci strain & - & $\begin{array}{l}+ \\
+\end{array}$ & $\begin{array}{l}+ \\
+\end{array}$ \\
\hline isolated from a parakeet & - & + & \\
\hline Chlamydia trachomatis & & & \\
\hline
\end{tabular}

\section{$M=123456$ \\ $1353 \mathrm{bp}-$ \\ $1078 \mathrm{bp}-$ \\ 872 bp \\ $603 \mathrm{bp}-$
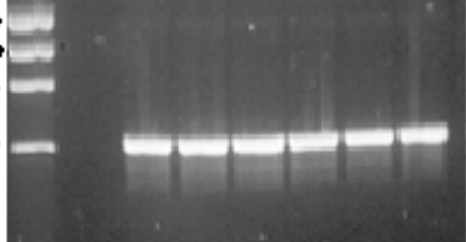 \\ $606 \mathrm{bp}$}

Fig. 1. Detection of iro $B$ gene by PCR.

Şekil 1. iroB geninin PCR ile saptanması.

M. 100-bp DNA ladder (Fermentas, Vilnius, Lithuania). -: Escherichia coli as negative control. Lane 1: positive control. Lanes 2-6: PCR amplicons of Salmonella strains. Lane 2: S. Enteritidis. Lane 3: $S$. Typhimurium. Lane 4: S. Gallinarum. Lane 5: S. Pullorum. Lane 6: Salmonella spp. isolate from a caged bird.

M. 100-bp'lik DNA marker (Fermentas, Vilnius, Litvanya). -: Negatif kontrol, Escherichia coli. Hat 1: pozitif kontrol. Hatlar 2-6: Salmonella suşlarından elde edilen PCR ürünleri. Hat 2: $S$. Enteritidis. Hat 3: $S$. Typhimurium. Hat 4: $S$. Gallinarum. Hat 5: S. Pullorum. Hat 6: Salmonella spp. isolate from a caged bird.

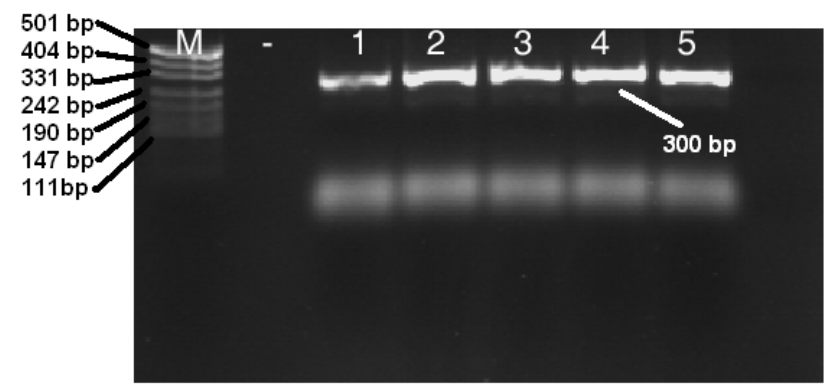

Fig. 2. Detection of $p m p$ genes by PCR.

Şekil 2. Pmp genlerinin PCR ile saptanması.

M. pUC19 DNA/MspI (25-bp) Marker, 23 (Fermentas, Vilnius, Lithuania). -: C. trachomatis as negative control. Lane 1: C. psittaci strain 6BC. Lane 2: C. psittaci strain isolated from a parakeet. Lanes 35: DNAs extracted from ocular swab, intestine, feces, respectively, of a death caged bird.

M. pUC19 DNA/MspI Marker, 23 (Fermentas, Vilnius, Litvanya). -: Negatif kontrol, C. trachomatis. Hat 1: C. psittaci 6BC suşu. Hat 2: Bir papağandan izole edilmiş $C$. psittaci suşu. Hatlar 3-5: Ölü bir kafes kuşundan örneklenen göz, bağırsak ve dışkı svablarından ekstrakte DNA'lar.

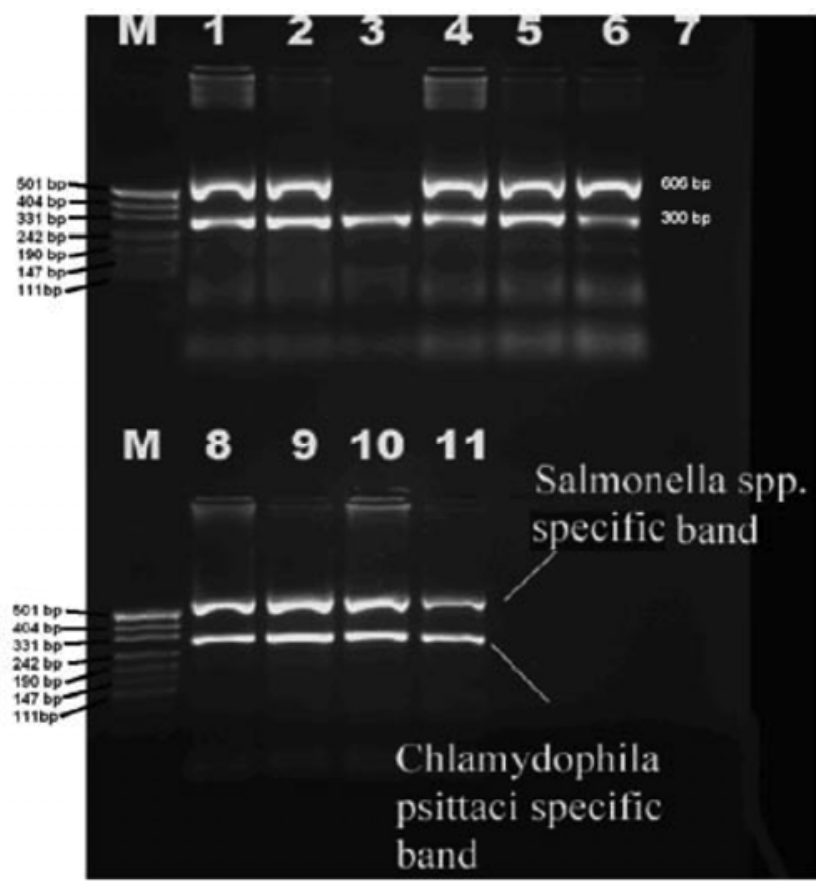

Fig. 3. Multiplex-PCR detection of $i r o B$ and $p m p$ genes. Şekil 3. IroB ve $p m p$ genlerinin m-PZR ile saptanmas1. M. pUC19 DNA/MspI (25-bp) Marker, 23 (Fermentas, Vilnius, Lithuania). Lanes 1 and 2: positive controls. Lane 1:S. Enteritidis with C. psittaci strain 6BC. Lane 2: $S$. Typhimurium with C. psittaci strain isolated from a parakeet. Lane 3: DNA extracted from the ocular swab from the caged bird. Lanes 4-6: DNA extracted from internal organs (liver, spleen, lungs). Lane 7: DNA extracted from E. coli strain as negative control. Lanes 8 and 9: DNA extracted from intestines. Lanes 10 and 11: DNA from cloacal swab and feces, respectively.

M. pUC19 DNA/MspI Marker, 23 (Fermentas, Vilnius, Lithuania). Hat 1 ve 2: pozitif kontroller. Hat 1: $S$. Enteritidis ve $C$. psittaci $6 \mathrm{BC}$ suşu. Hat 2: $S$. Typhimurium ve bir papağandan izole edilmiş $C$. psittaci suşu. Hat 3: Kafes kuşundan alınan göz svabından ekstrakte edilmiş DNA. Hatlar 4-6: İç organlardan (karaciğer, dalak, akciğerler) ekstrakte edilmis DNA'lar. Hat 7: E. coli suşundan ekstrakte edilmiş DNA, negative kontrol. Hat 8 ve 9: Bağırsaklardan ekstrakte edilen DNA'lar. Hat 10 ve 11: Sırasıyla, kloakal svab ve dışkıdan elde edilmiş DNA'lar.

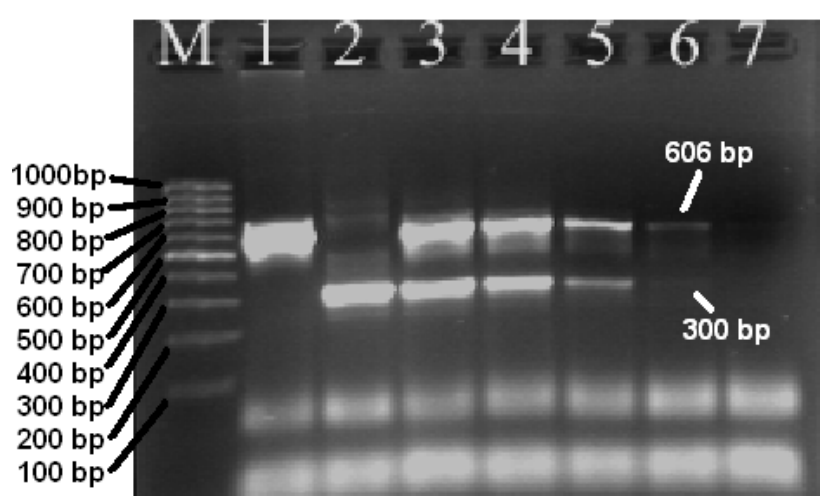

Fig. 4. Determination of the sensitivity of m-PCR assay. Şekil 4. M-PZR tekniğinin sensitivitesinin belirlenmesi.

M. GeneRuler ${ }^{\mathrm{TM}} 100-$ bp DNA ladder (Fermentas, Vilnius, Lithuania). Lane 1: M-PCR with Salmonella DNA only. Lane 2: M-PCR with $C$. psittaci DNA only. Lanes 3-7: M-PCR tests with Salmonella and $C$. psittaci DNAs of respectively $20 \mathrm{ng}, 2 \mathrm{ng}, 200 \mathrm{pg}, 20 \mathrm{pg}$ and $2 \mathrm{pg}$.

M. 100-bp DNA marker (Fermentas, Vilnius, Litvanya). Hat 1: Sadece Salmonella DNA ile yapılan m-PZR. Hat 2: Sadece C. psittaci DNA ile yapilan m-PZR. Hatlar 3-7: Sirasiyla $20 \mathrm{ng}, 2 \mathrm{ng}, 200 \mathrm{pg}, 20 \mathrm{pg}$ ve 2 pg'lik Salmonella ve $C$. psittaci DNA'sı içeren örneklerle yapılan mPZR testleri. 


\section{Discussion and Conclusion}

We established and used a m-PCR assay for the detection of Salmonella and C. psittaci in caged birds. Isolation of $C$. psittaci from clinical samples is very difficult and laborious and requires inoculations to cell cultures and embryonated eggs. Additionally, it is important to apply appropriate biosafety precautions while working with $C$. psittaci. Therefore, we included C. psittaci primers to Salmonella PCR mix to establish a primer cocktail that could detect any or both of the agents, which will increase the practicability of detection. M-PCR assays are becoming prevalent for the simultaneous detection of toxins, virulence factors and pathogens in clinical and environmental specimens (24). Although there are studies of m-PCR for the investigation of avian agents in avian medicine, particularly, in chickens $(1,21)$, we encountered a few in the case of caged birds (17).

It is likely that the assay is specific for the detection of Salmonella and C. psittaci, since we detected only Salmonella spp. and C. psittaci DNA in the test, and no non-specific amplification of DNA from different bacteria was observed.

The m-PCR assay was found sensitive, since it could detect both DNAs at dilutions of $20 \mathrm{pg}$. Laroucau et al. (14) detected up to $5 \mathrm{pg}$ of $C$. psittaci DNA dilution with the same primers. This slight difference could be originated from the multiplexing of PCR, interactions between the primer pairs and the amplification mixes, and also from the different DNA extraction methods used in the studies.

The test lasted for $4 \mathrm{~h}$ overall, from extraction to electrophoresis. The assay is economic, because it employs the same reaction reagents and consumables for the investigation and detection of two different bacteria simultaneously from the common DNA preparation in the same tube.

In this study, we managed to detect both Salmonella and C. psittaci DNA directly from internal organs, intestines and feces obtained from a dead canary. Molecular detection of Salmonella in clinical materials may require a pre-enrichment procedure. PCR with preincubation in an enrichment broth has been found to be a useful and more rapid method because it increases the number of viable Salmonella spp. in the sample and, therefore, increases the sensitivity of the assay (4). We believe implication of a pre-enrichment procedure to the method should increase the sensitivity of the assay. The efficacy of the assay has to be determined with sufficient number and diversity of both artificially spiked tissue samples and clinical materials such as feces and other tissue samples. Feces or blood contain PCR inhibitors that hinder the detection of specific DNA and result with false negative results (15). Either the dilution of the extracted DNA and repeat of PCR or addition of PCR enhancers (2) or implying nested primers to PCR (nested PCR) to improve test sensitivity is suggested (25). Another choice is addition of an internal control into PCR reactions which we believe is another strategy to determine the possible participation of inhibitors. We compared BSA and DMSO as the probable enhancer to be used in the assay and gathered better results with the addition of DMSO at a concentration of $0.2 \%(\mathrm{v} / \mathrm{v})$ (data not shown).

As a conclusion, we believe this is the first report of a m-PCR assay for the detection of Salmonella spp. and C. psittaci DNA. Also reported for the first time was the co-existence of both agents in avian clinical samples (feces, intestines and internal organs) obtained following the necropsy of a dead caged bird.

\section{Acknowledgements}

Authors cordially acknowledge Prof. Bernhard Kaltenboeck (Department of Pathobiology, College of Veterinary Medicine, Auburn University) for provision of control DNAs.

\section{References}

1. Ali A, Reynolds DL (2000): A multiplex reverse transcription-polymerase chain reaction assay for Newcastle disease virus and avian pneumovirus (Colorado strain). Avian Dis, 44, 938-943.

2. Al-Soud WA, Radstrom P (2000): Effects of amplification facilitators on diagnostic $P C R$ in the presence of blood, feces, and meat. J Clin Microbiol, 38, 4463-4470.

3. Baumler AJ, Heffron F, Reisbrodt R (1997): Rapid detection of Salmonella enterica with primers specific for iroB. J Clin Microbiol, 35, 1224-1230.

4. Carli KT, Unal CB, Caner V, Eyigor A (2001): Detection of salmonella in chicken feces by a combination of tetrathionate broth enrichment, capillary PCR, and capillary gel electrophoresis. J Clin Microbiol, 39, 18711876.

5. Elnifro EM, Ashshi AM, Cooper RJ, Klapper PE (2000): Multiplex PCR: optimization and application in diagnostic virology. Clin Microbiol Rev, 13, 559-570.

6. Everett KDE, Hornung LJ, Andersen AA (1999): Rapid detection of the Chlamydiaceae and other families in the order Chlamydiales: three PCR tests. J Clin Microbiol, 37, 575-580.

7. Eyigor A, Carli KT (2003): Rapid detection of Salmonella from poultry by real-time polymerase chain reaction with fluorescent hybridization probes. Avian Dis, 47, 380-386.

8. Grimes JE (1987): Zoonoses acquired from pet birds. Vet Clin North Am Small Anim Pract, 17, 209-218.

9. Henegariu O, Heerema NA, Dlouhy SR, Vance GH, Vogt PH (1997): Multiplex PCR: critical parameters and step-by-step protocol. Biotechniques, 23, 504-511. 
10. Herring AJ (1993): Typing Chlamydia psittaci-a review of methods and recent findings. Br Vet J, 149, 455-475.

11. Hewinson RG, Griffiths PC, Bevan BJ, Kirwan SES, Field ME, Woodward MJ, Dawson M (1997): Detection of Chlamydia psittaci DNA in avian clinical samples by polymerase chain reaction. Vet Microbiol, 54, 155-166.

12. Hewinson RG, Rankin SES, Bevan BJ, Field M, Woodward MJ (1991): Detection of Chlamydia psittaci from avian field samples using the PCR. Vet Rec, 128, 129-130.

13. Hong Y, Liu T, Hofacre C, Maier M, White DG, Ayers S, Wang L, Maurer JJ (2003): A restriction fragment length polymorphism-based polymerase chain reaction as an alternative to serotyping for identifying Salmonella serotypes. Avian Dis, 47, 387-395.

14. Laroucau K, Souriau A, Rodolakis A (2001): Improved sensitivity of PCR for Chlamydophila using pmp genes. Vet Microbiol 82, 155-164.

15. Malorny B, Hoorfar J (2005): Toward standardization of diagnostic PCR testing of fecal samples: lessons from the detection of Salmonellae in pigs. J Clin Microbiol, 43, 3033-3037.

16. McElnea CL, Cross GM (1999): Methods of detection of Chlamydia psittaci in domesticated and wild birds. Aust Vet J, 77, 516-521.

17. Messmer TO, Skelton SK, Moroney JF, Daugharty H, Fields BS (1997): Application of a nested, multiplex PCR to psittacosis outbreaks. J Clin Microbiol, 35, 2043-2046.

18. Moroney JF, Guevara R, Iverson C, Chen FM, Skelton SK, Messmer TO, Plikaytis B, Williams PO, Blake P, Butler JC (1998): Detection of chlamydiosis in a shipment of pet birds, leading to recognition of an outbreak of clinically mild psittacosis in humans. Clin Infect Dis, 26, 1425-1429.
19. Olsen B, Persson K, Broholm KA (1998): PCR detection of Chlamydia psittaci in faecal samples from passerine birds in Sweden. Epidemiol Infect, 121, 481-484.

20. Orosz SE, Chengappa MM, Oyster RA, Morris PJ, Trock S, Altekruse S (1992): Salmonella enteritidis infection in two species of Psittaciformes. Avian Dis, 36, 766-769.

21. Pang Y, Wang H, Girshick T, Xie Z, Khan MI (2002): Development and application of a multiplex polymerase chain reaction for avian respiratory agents. Avian Dis, 46, 691-699.

22. Riyaz-Ul-Hassan S, Verma V, Qazi GN (2004): Rapid detection of Salmonella by polymerase chain reaction. Mol Cell Probes, 18, 333-339.

23. Ryan TP (1985): Salmonellosis in caged birds. Mod Vet Pract, 66, 383-385.

24. Singh DV (2003): Hexaplex PCR for rapid detection of virulence factors. Expert Rev Mol Diagn, 3, 781-784.

25. Wilson IG (1997): Inhibition and facilitation of nucleic acid amplification. Appl Environ Microbiol, 63, 37413751.

Geliş tarihi: 04.05.2007 / Kabul tarihi: 22.02.2008

\author{
Address for correspondence: \\ Dr. Barış Sareyyüpoğlu \\ Department of Microbiology, \\ Faculty of Veterinary Medicine, \\ Ankara University, 06110, Dışkapı, \\ Ankara/Turkey. \\ e-mail:sareyyupoglu@veterinary.ankara.edu.tr
}

